Milica S. Stanković

Univerzitet u Kragujevcu

Filološko-umetnički fakultet

/doktorand na Filološkom fakultetu UB/**
821.111(73).09-31 Фокнер В.

821.134.2(862).09-31 Маркес Г. Г. https://doi.org/10.18485/analiff.2019.31.2.3

Originalni naučni rad

Primljen: 22.07.2019

Prihvaćen: 23.09.2019

\title{
ISTORIJA, TRAGIČNOST I IRONIJA U ROMANIMA AVESALOME, AVESALOME! VILIJAMA FOKNERA I STO GODINA SAMOĆE GABRIJELA GARSIJE MARKESA
}

Rad se bavi uporednom analizom romana Avesalome, Avesalome! Vilijama Foknera (William Faulkner) i Sto godina samoće Gabrijela Garsije Markesa (Gabriel García Márquez), posebno se usredsređujući na njihovo sagledavanje prošlosti i elemenata tragedije. Polazeći od Foknerovog uticaja na latinoamerički „Bum“, preko koncepata Joknapatofe i Makonda i postmodernističkog pristupa istoriji, ovaj rad nastoji da prikaže čvrstu vezu između Foknerovog i Markesovog prikazivanja elemenata tragične prošlosti junaka koja je neodvojiva od njihove sadašnjosti i koja će ih pratiti sve do apokaliptičnog kraja. Posebna pažnja posvećena je elementima ironije, koji su ključni za svaki pokušaj oživljavanja istorije, ali koji su, kao što će se pokazati, mnogo dominantniji u Markesovom romanu, te tako čine osnovnu razliku između njegovog i Foknerovog pristupa konceptu tragičnosti.

Ključne reči: Fokner, Markes, istorija, istoriografska metafikcija, tragedija, ironija

Mnogi latinoamerički pisci druge polovine 20. veka naglašavali su veliki uticaj koji je Vilijam Fokner (William Faulkner) izvršio na njihovo stvaralaštvo, posebno kada je u pitanju prikazivanje istorije i tragične prošlosti njihovih zemalja. Svojom živom i sveobuhvatnom slikom američkog Juga koju je uspeo na uzdigne na univerzalni nivo, Fokner je latinoameričkim piscima pružio model koji će im pomoći da, najpre sagledaju sopstvenu stvarnost, te da je potom ožive i upotpune kroz fikciju. Foknerov uticaj

\footnotetext{
*_mstankovic994@gmail.com

** Završni rad napisan za kurs Savremeni američki roman, u okviru doktorskih studija na Filološkom fakultetu u Beogradu, pod mentorstvom prof. dr Radojke Vukčević
} 
posebno mesto pronašao je u prozi Gabrijela Garsije Markesa (Gabriel García Márquez) koji ga je, u svom govoru prilikom uručenja Nobelove nagrade, nazvao „svojim velikim učiteljem“ (1987: 211) i čija dela istom snagom govore, kako o kolumbijskoj realnosti, tako i o patnjama čitave Latinske Amerike.

Kada se govori o međusobnom prožimanju tema i motiva Foknerovog i Markesovog stvaralaštva, najviše se paralela može uočiti između Foknerovog romana Avesalome, Avesalome! i Markesovih Sto godina samoće, jer oba romana snažno preispituju, najpre odnos prema sopstvenoj istoriji, a zatim i njen uticaj na pojedince. Ovaj rad posebno se bavi takvim elementima, dajući uvid u Foknerovo i Markesovo sagledavanje tragedija koje su deo kolektivne prošlosti i koje određuju životni put svakog od njihovih junaka. Prvi deo rada predstavlja osvrt na tematske i strukturne odlike Foknerovog stvaralaštva koje su postale deo književnosti Latinske Amerike i koje su jednim delom zaslužne za veliki procvat koji je latinoamerička proza doživela tokom pedesetih i šezdesetih godina prošlog veka. Zatim, drugi deo daje uvid u osnovne sličnosti između izmaštanih mesta, Joknapatofe i Makonda, koje su Fokner i Markes podarili svojim kulturama i koja predstavljaju, kako upotpunjenu sliku stvarnih mesta kojima su inspirisane, tako i univerzalnu sliku ljudskih nedaća koja prevazilazi ove okvire. Treći deo bavi se konceptom istoriografske metafikcije i načinom na koji i Fokner i Markes preispituju granice između istorije i pripovedanja, dok je u poslednjem delu fokus preusmeren na analizu likova oba romana i njihovih tragedija koje su kod Foknera naglašene, dok se kod Markesa skrivaju ispod elemenata ironije, mašte i, vrlo često, apsurda.

\section{Fokner i Latinska Amerika}

Sredina 20. veka donela je velike promene u latinoameričkoj književnosti, kako po pitanju tematike, tako i u pogledu pripovednih postupaka, te se zbog upadljivog odvajanja od tradicionalnih metoda i izuzetne inovativnosti koja ga karakteriše, ovaj period najčešće naziva latinoameričkim „Bumom“. Najznačajniji pisci ovog perioda, kao što su Gabrijel Garsija Markes, Karlos Fuentes (Carlos Fuentes), Hulio Kortasar (Julio Cortázar), Mario Vargas Ljosa (Mario Vargas Llosa) i mnogi drugi, u nedostatku direktnih uticaja iz sopstvenih književnih tradicija uzore su pronalazili u piscima koji su pomerali granice tradicionalnih književnih postu- 
paka. Pored Franca Kafke (Franz Kafka), Džejmsa Džojsa (James Joyce) i Ernesta Hemingveja (Ernest Hemingway), kao najznačajnija figura čiji su značaj naglašavali mnogi ,pisci Buma“ izdvaja se Vilijam Fokner. Foknerovi koncepti zajednice, vremena, istorije, tragedije i samoće, kao i njegovi opisi međuljudskih odnosa, prirode, zemlje, industrijalizacije i način predstavljanja stvarnosti kao dvosmislenog i promenljivog koncepta pronašli su put do ovih autora, koji su želeli da predstave viziju sopstvenih zemalja i kultura u svoj njihovoj punoći i raznolikosti (Hamblin \& Peek, 1999: 219). Kako navodi Mario Vargas Ljosa, stvarnost na osnovu koje je Fokner kreirao svoj sopstveni književni svet vrlo je slična stvarnosti Latinske Amerike koju su on i drugi pisci pokušavali da prikažu - u Latinskoj Americi, kao i na američkom Jugu zajedno žive dve različite kulture, dve istorijske tradicije, dve rase, a takva zajednica puna je predrasuda i nasilja (prema Hamblin \& Peek, 1999: 221). Ovu sličnost naglašava i Karlos Fuentes, prema čijem mišljenju se značaj Foknera ogleda upravo u svesti da elementi tragedije, kao i svest o razdvojenosti dolaze iznutra, iz samog jezgra američkog društva, a Foknerova veličina jeste u njegovoj sposobnosti da ih prepozna i iz njih stvori univerzalnu književnost (Márquez, 1992: 16). Nadalje, prema Fuentesu jedino Fokner, od svih američkih pisaca, iz tog „uskog sveta optimizma i uspeha“, nudi sliku stvarnosti koja je zajednička Severnoj i Južnoj Americi: sliku poraza, razdvojenosti, sumnje i tragedije (prema Márquez, 1992: 17). Dakle, ono čemu su se ovi pisci posebno divili jeste Foknerova sposobnost da prikaže tragedije sopstvene zemlje i sopstvenog naroda na način koji će te tragedije približiti svakom čitaocu, bez obzira na pripadnost određenoj tradiciji i kulturi. Kako navodi pisac Ernesto Delgado (Ernesto Delgado), Fokner je latinoameričke pisce naučio da ,vide stvarnost, a da pritom ne poriču lepotu njene tragičnosti“ (1997: 34). Takođe im je, moglo bi se dodati, pružio potporu za drugačije sagledavanje sopstvene istorije i koncepta prošlosti, koji za njega predstavljaju neodvojivi deo svakog pojedinca. Fuentes ističe da je jedno od najvećih Foknerovih dostignuća eksperimentisanje sa narativnim vremenom, koje dovodi do ukidanja prošlosti kao koncepta koji prethodi sadašnjosti - prošlost je za Foknera ,deo svakog muškarca, svake žene, svakog trenutka“", u njegovim romanima sve se dešava sada, a čovek je „zbir sopstvene prošlosti“ (prema Márquez, 1992: 17). Takvoj sposobnosti prikazivanja istorije i njene tragičnosti Gabrijel Garsija Markes daje na- 
ziv „foknerovski metod“ i navodi da je to najprikladnija tehnika kojom se može pripovedati o latinoameričkoj stvarnosti:

To je ono što smo nesvesno otkrili kod Foknera. Odnosno, posmatrali smo ovu stvarnost i želeli da o njoj govorimo, ali znali smo da ni evropski metod, a ni onaj tradicionalni španski neće poslužiti; i odjednom smo shvatili da je foknerovski metod vrlo adekvatan za prikazivanje ove stvarnosti. Zapravo, to i ne čudi, jer okrug Joknapatofa izlazi na Karipsko more. Tako da je on, na neki način, latinoamerički pisac. (prema Hamblin \& Peek, 1999: 222) ${ }^{1}$

Na sličan način, Mario Vargas Ljosa zaključuje da je Fokner, iako je pisao na engleskom jeziku, bio ,jedan od njih“ (prema Márquez, 1992: 22). Foknera i Latinsku Ameriku povezuje, dakle, snažna potreba da se sagleda i razume sopstvena istorija, kako bi se stvorila što sveobuhvatnija slika o njenim slavnim momentima i tragedijama koje su utkane u suštinu svakog pojedinca, i koje, bez obzira na to što su deo jednog naroda i jedne kulture, poseduju univerzalnu vrednost.

\section{Joknapatofa i Makondo}

Najjača spona između Foknerove slike američkog Juga i fiktivne predstave Latinske Amerike otelovljena je u piscu koji je, prema brojnim kritičarima, hispanoameričkoj književnosti podario ono što je jedan od njegovih glavnih uzora pružio književnosti severnoameričkog kontinenta. Ogroman doprinos sopstvenoj kulturi Gabrijela Garsije Markesa ogleda se u njegovom stvaranju fiktivnog sela Makonda, koje predstavlja, kako mnogi naglašavaju, latinoamerički ekvivalent Foknerovog okruga Joknapatofe i grada Džefersona. Kao što Fokner izražava dramu uništenog i otuđenog Juga posredstvom hronike jednog mesta, tako i Markes rasvetljava nesreće Makonda stvarajući selo koje često nazivaju „mikrokosmosom kolumbijske realnosti“ (Delay \& De Labriolle, 2009: 131).

Premda se ne može poreći da i Joknapatofa i Makondo jesu odraz stvarnih mesta i da svedoče o istinskim sudbinama ljudi u njima, posmatrati ove koncepte isključivo kao umanjene prikaze stvarnosti značilo bi pojednostaviti njihovu ulogu u svetu književnosti, jer se njihova veličanstvenost ogleda upravo u univerzalnim vrednostima koje se u njima mogu

1 Svi navodi strane literature dati su u prevodu autorke ovog rada 
pronaći. Prema rečima kritičara Čarlsa Ajkena (Charles Aiken), Joknapatofa je, pre nego mikrokosmos Juga, mikrokosmos unutar njega i sa književne tačke gledišta predstavlja „mnogo više“, posebno kada uzmemo u obzir da je Fokner, kako je i sam govorio, težio da prikaže univerzalno ljudsko iskustvo (1979: 348). Pisac, kako navodi Fokner, nema vremena da stvara sliku čitavog regiona, te to i nije bila njegova namera, već je, „koristeći jedino oruđe koje je posedovao, a to je zemlja koju je dobro poznavao“, nastojao da govori o „nesrećama, nevoljama i patnjama ljudskog srca koje je univerzalno", zajedničko svima, bez obzira na rasu, jedan vremenski trenutak, ili određene uslove (prema Aiken, 1979: 347-48). Na sličan način, Makondo predstavlja mnogo više od kolumbijske stvarnosti. Kako u svojoj studiji o romanu Sto godina samoće navodi Majkl Vud (Michael Wood), Markes uzima konkretnu kolumbijsku stvarnost u kojoj briše oznake, ali tako da ona time ne postaje ništa manje kolumbijska, već prestaje da bude isključivo kolumbijska (1990: 8). Takođe, kako naglašava ovaj kritičar, iako bismo, praveći geografsku mapu na osnovu opisa iz romana došli do zaključka da se Makondo nalazi u Kolumbiji, njena svrha ne bi bila da nam pokaže da se radnja romana odigrava baš tamo - da je Markes želeo da nam da naziv zemlje, on bi to i učinio - već da se njegova geografija i istorija nimalo ne razlikuju od kolumbijske i da bi se izmaštani svet zaista mogao smestiti u konkretno vreme i prostor (1990: 27). Ovde je, kako zaključuje, analogija sa Foknerovom Joknapatofom jasna - grad Džeferson nećemo naći ni na jednoj mapi Misisipija, ali on nigde drugde na čitavom svetu ne može biti (1990: 27).

Dakle, Foknerovi i Markesovi fiktivni svetovi nikako nisu puko podražavanje stvarnosti, već ovi pisci zapravo stvarnost „koriste“ kako bi stvorili svet koji uveliko prevazilazi njene granice. Dok, s jedne strane, kod Foknera stvarnost, bilo da je to scena ili pejzaž, teži ka nadrealnom, Markesov magijski realizam temelji se na tretiranju elemenata fantastike kao da su stvarni, te tako stvarnost i imaginaciju dovodi na isti ontološki nivo (Delay \& De Labriolle, 2009: 143). Stoga, kako primećuje Ernesto Delgado, ni Foknerova književna stvarnost, ni Markesov magijski realizam ne reflektuju uvek stvarni svet, jer stvaranje fikcije podrazumeva kompleksni proces u kome se pisac nikada u potpunosti ne predaje stvarnosti koja mu je data, već zamišlja i popunjava jazove između istorijskih događaja i onoga što se moglo desiti svojim sopstvenim iskustvom (1997: 34). Ako 
bismo se zaputili u Latinsku Ameriku, nastavlja Delgado, tamo svakako ne bismo pronašli bajkovite i fantastične elemente iz Markesovih romana, jer oni zapravo predstavljaju veličanstvenu metaforu latinoameričkih vrednosti i misli koje je Markes u svojim delima uspešno pretočio u reči:

Markesov Makondo je poput slike Juga u Foknerovoj Joknapatofi. Znamo šta je stvarno, a šta ne, znamo da današnji Jug nije onaj Jug iz Foknerovih košmara, kao što znamo da ni Latinska Amerika nije ona iz Markesovih maštarija. Ali takođe moramo priznati da je ono što oni govore istinito. Makondo je „na neki način“ Latinska Amerika, kao što je Joknapatofa „na neki način“ američki Jug. Čitajući Foknera i Markesa ta mesta možemo da osetimo. (Delgado 1997: 35)

I zaista, suština Foknerovih i Markesovih izmaštanih svetova jeste da se stvarna mesta dožive i osete mnogo snažnije i potpunije nego što je to moguće u stvarnosti. Kako u svojim esejima zaključuje Mario Vargas Ljosa, važnost fikcije se ogleda u tome što ona „upotpunjuje život", dodajući ljudskom iskustvu nešto što se ne može sresti u stvarnom životu, već samo u izmaštanim životima koje proživljavamo na indirektan način, kroz fikciju (1997: 157).

\section{Rekonstrukcija istorije}

Kompleksnom odnosu stvarnosti i fikcije kod Vilijama Foknera i Gabrijela Garsije Markesa posebno doprinosi tema spoznaje i rekonstrukcije istorije, što se lako da primetiti kada se zajedno posmatraju Markesov roman Sto godina samoće i Foknerov roman koji se najeksplicitnije bavi „teretom južnjačke prošlosti“ (Hobson, 2003: 4), a to je svakako Avesalome, Avesalome!. U ovom romanu, kako ističe Brajan Mekhejl (Brian McHale) u svojoj studiji o postmodernističkoj prozi (1987), Fokner se u jednom trenutku odvaja od poetike modernizma i priču gradi na način svojstven postmodernističkom pogledu na svet. Kako bi ovo ilustrovao, Mekhejl objašnjava da je dominanta modernističke proze u osnovi „epistemološka“, te da su pitanja koja ona ostavlja usmerena na mogućnost spoznaje sveta: „Šta se može saznati? Ko to zna i sa kakvom sigurnošću? Kako se znanje prenosi sa jednog pojedinca na drugog i koliko je ono pouzdano?"“ itd (1987: 9). Uzimajući kao centralnu temu rekonstrukciju 
priče o Tomasu Satpenu od strane više junaka, nema sumnje da je Fokner ovaj roman konstruisao tako da postavlja baš ova pitanja. Međutim, prema Mekhejlu, značajan preokret se događa u osmom poglavlju romana, kada Kventin Kompson i njegov kolega sa Harvarda, Šriv Makenon, dolaze do granica svog saznanja o tome šta se desilo sa Satpenom, pa prelaze „sa rekonstrukcije na spekulaciju“ (1987: 10). Sama uloga lika kao što je Šriv izuzetno je značajna, jer je on jedina osoba koja nije direktno povezana sa pričom, te se njegova percepcija događaja temelji samo na onome što saznaje od Kventina, koji mu prepričava ono što je čuo od svog dede i Roze Koldfild, sestre Satpenove supruge. Na taj način, Satpenova istorija prolazi kroz više filtera, tako da ju je na kraju moguće rekonstruisati samo uz pomoć nagađanja i subjektivnih zaključaka. Kako zaključuje Mekhejl, misterija Satpenovog ubistva se rešava, ali ne kroz epistemološki proces analiziranja dokaza i dedukcije, već kroz zamišljenu projekciju onoga što je moglo i moralo da se desi, te tu dolazi do preusmerenja pažnje sa problema saznanja na problem postojanja - sa epistemološke dominante na ontološku (1987: 10). Avesalome, Avesalome! je, dakle, kritika istorije i afirmacija njene neizbežne konstruktivnosti, te tako nagoveštava postmoderni pristup istoriji koji Linda Hačen (Linda Hutcheon) naziva istoriografskom metafikcijom (Parrish 2008: 43). Postmodernistički pristup prošlosti, kako Hačen objašnjava u Poetici postmodernizma, pored problema spoznaje preispituje i ontološki status prošlosti, njenih dokumenata i narativa (1988: 50). Nadalje, ova teoretičarka takođe objašnjava da istoriografska metafikcija podrazumeva svest o istoriji i fikciji kao konstruktima koji se temelje na preispitivanju i ponovnom sagledavanju formi i sadržaja prošlosti (1988: 5). Prema tome, iako ovaj roman nije postmodernistički tekst, Foknerovo pripovedanje izaziva izuzetnu skeptičnost prema stavu da se prošlost može odvojiti od pripovedanja, jer istorija nije samo prošlost, već ispričana prošlost - prošlost je diskurs, pripovest (Parrish, 2008: 43-44).

Premda se roman Avesalome, Avesalome! u celini ne može smestiti $\mathrm{u}$ žanr istoriografske metafikcije i da se on, prema Lindi Hačen, pre može definisati kao „metaistorijski roman“ (1988: 88), ne može se poreći da je Foknerova vizija južnjačke istorije značajno uticala na potonje pisce. Kako navodi Hačen, proizvoljna, neodređena priroda istorijskog znanja svakako nije izum postmodernizma, kao ni preispitivanje epistemološkog i ontološkog statusa istorijskih činjenica, ali je usredsređenost na ove probleme 
u epohi postmodernizma znatno veća nego ranije (1988: 88). Ono što posebno karakteriše postmoderni odnos prema istoriji, odnosno istoriografsku metafikciju, jeste svakako ironija sa kojom se pristupa sagledavanju pređašnjih događaja, a opšti zaključak predstavlja zapažanje Umberta Eka (Umberto Eco) da se prošlost sada može sagledati samo ,ironično, a ne bezazleno" (Eko, 2004: 472). Ovakvu vrstu kritičkog pristupa istoriji pronalazimo kako kod Foknera, tako i kod Markesa, ali se Sto godina samoće, kao ni Avesalome, Avesalome! ne može smatrati tipičnim primerom istoriografske metafikcije, bez dodatnih napomena da u nekim svojim karakteristikama izlazi iz ovih okvira. Iako Hačen ovaj roman navodi kao jedan od primera postmodernog pristupa istoriji, ona objašnjava da se o njemu često govori sa sasvim drugačije tačke gledišta, jer pored toga što svakako predstavlja primer metafikcije i samoreflektivnosti, on veoma snažno govori o političkoj i istorijskoj stvarnosti Kolumbije (1988: 5). Sposobnost da o stvarnosti koja ih okružuje govore na način koji je, s jedne strane, potpuno realističan, a s druge posredovan istorijskom distancom svojstven je i Fokneru i Markesu. Ako se uzme u obzir da je istoriografska metafikcija „istorijska“, ali na jedan ironičan i problematičan način koji potvrđuje da istorija nikako nije zapis bilo kakve „sigurne istine“ (1988: 128), jasno je zašto Markesov roman, premda dosta bliži ovom pojmu od Foknerovog, sadrži elemente koji mu protivreče. Kao što iz Foknerove priče o Tomasu Satpenu izviru najdublje istine i strahovi američkog Juga, posebno one vezane za rasizam, ropstvo i Građanski rat, tako i u sagi o porodici Buendija, ispod Markesove karakteristične ironije, pronalazimo stvarnu predstavu ključnih događaja kolumbijske istorije, poput neprestanih sukoba između liberala i konzervativaca i masovnog ubistva radnika iz fabrike banana.

Kod Foknera se istorijska distanca čija je funkcija ostvarivanje kritičkog odnosa prema istoriji postiže kroz različite tačke gledišta više junaka koji priču rekonstruišu. S druge strane, kod Markesa se ona postiže svešću o krhkosti ljudskog sećanja, kao i otkrivanjem proročkih spisa koje je ostavio Melkijades, lik koji u najvećoj meri sažima magijske elemente romana. Međutim, dok smo kod Foknera sve vreme svesni prisustva pripovedača koji nam otkrivaju Satpenovu priču, kod Markesa tek u poslednjem pasusu saznajemo da priču o Makondu pripoveda Melkijades, a ne sveznajući pripovedač (Zamora, 2006: 198). Ipak, već se u čuvenoj prvoj rečenici romana Sto godina samoće: „Mnogo godina kasnije, pred strojem za 
streljanje, pukovnik Aurelijano Buendija morao je da se seti onog davnog popodneva kada ga je otac poveo da upozna led" (Markes, 1976: 7), uvodi ideja o sećanju i zaboravu kao ključnim konceptima koji će oblikovati istoriju Makonda. Pored toga, svojom neodređenošću, Markesova prva rečenica najpre reflektuje glavne teme romana, a zatim i način sagledavanja prošlosti. Zahvaljujući proizvoljnim vremenskim odrednicama „mnogo godina kasnije“ i ,onog davnog popodneva“, ova rečenica u isti mah sadrži i prošlost i sadašnjost i budućnost (Meyers, 1986: 33), što predstavlja jednu od ključnih odlika Markesovog konstruisanja narativnog vremena. Melkijades, naime, prepričava prošlost, sadašnjost i budućnost Makonda, sa tačke gledišta koja je ,izvan budućnosti“, on neprestano povezuje pređašnje događaje sa kasnijim u ,retrospektivnom budućem vremenu“, zato što su sudbine likova već poznate. (Zamora, 2006: 184). Takav paradoks „bezvremenog vremena“ koje likove zatvara u jedan istorijski trenutak ujedno predstavlja i snažnu vezu sa Foknerom, jer zajednička istorija koju on rekonstruiše nije klasična priča o prošlosti koja se prenosi sa kolena na koleno, već se stvara utisak da se čitava priča može smestiti u taj jedan trenutak (Parrish, 2008: 51). Tako na primer Kventin Kompson, dok ponovo oživljava priču o Satpenu 1909. godine, oseća da još uvek udiše ,isti vazduh u kome su crkvena zvona brujala onog nedeljnog popodneva 1833. godine“ - dana kada je Tomas Satpen došao u grad (Fokner, 1978: 62). Kod Markesa, na sličan način, raspon od osnivanja Makonda do njegovog kraja jeste dug, ali se višestrukim ponavljanjem imena koje novi likovi dobijaju po svojim precima i sličnim karakteristikama koje ih prate stiče utisak o kružnom vremenu, odnosno istoriji koja se neprestano ponavlja. Tako se recimo Ursula, supruga osnivača Makonda, Hosea Arkadija Buendije, takođe oseća zarobljeno u jednom istorijskom trenutku: „Ovo već znam napamet" - vikala je Ursula. - „To je kao da se vreme okreće ukrug, i kao da smo se vratili na početak“ (Markes, 1976: 206).

S druge strane, ambivalentan odnos prema istoriji, svojstven i Fokneru i Markesu, ogleda se u koncepciji priča koje teku od početka do kraja istorijskog vremena - od Postanja do Apokalipse. Opis Satpenovog dolaska i izgradnje njegove kuće u romanu Avesalome, Avesalome! prepun je aluzija na biblijsko stvaranje sveta:

Onda se u dugoj nezapanjenosti Kventinu činilo da ih posmatra kako najednom prekriljuju stotinu kvadratnih milja mirne 
i iznenađene zemlje i silom izvlače kuću i simetrične vrhove iz bezglasnog Ništa i naglo ih bacaju na tle kao da udaraju kartama o sto ispod nepomičnog i prvosvešteničkog gore okrenutog dlana stvarajući Satpenovu Stotinu. Neka bude Satpenova Stotina poput onog drevnog Neka bude svetlost.“ (Fokner, 1978: 42-43)

Na sličan način, Makondo je opisan kao svet toliko nov da stvari još uvek nisu imale imena:

Makondo je onda bilo selo od dvadeset kuća od blata i trske, sagrađeno na obali reke, čije su se bistre vode valjale kroz korito puno uglačanog kamenja, belog i velikog kao neka p re i storijska jaja. Svet je bio tako nov, mnoge stvari još nisu imale ime i, da bi se pomenule, trebalo ih je pokazati prstom. (Markes, 1976: 7)

Dakle, likovi oba romana osećaju se, na neki način, zarobljeno u vremenu, ali ono u oba slučaja neminovno vodi od slavnog početka do apokaliptičnog kraja. Kuća porodice Buendija praktično predstavlja „repliku kuće Satpenovih", jer ih prate ista shema, isti sjaj na početku i isto uništenje na kraju (Delay \& De Labriolle, 2009: 133). I Makondo i Satpenova Stotina osnovani su na temeljima nasilja i nepravde, koji su ih pratili sve do neslavnog kraja - Hose Arkadio Buendija ubija svog suparnika Prudensija Agilara, dok Tomas Satpen otima zemlju od Indijanaca i odriče se prve žene i sina zbog njihove crnačke krvi (2009: 132). Na taj način, i Foknerovu Joknapatofu i Markesov Makonda iznutra izjeda isto nasilje, ista sujeta i požuda (2009: 132), a njihov moralni pad predstavljen je kroz propast dveju porodica, tako što i jednu i drugu sustižu najdublji strahovi. U romanu Avesalome, Avesalome! to je miscegenacija, a u Sto godina samoće incest. Dok je poslednji izdanak porodice Satpen potomak Čarlsa Bona, Satpenovog odbačenog sina, te tako ima crnačke krvi, u porodici Buendija na kraju se, kao plod incesta, rađa dete sa svinjskim repom, što je od početka bio Ursulin najveći strah.

Oba romana se, dakle, završavaju tragično i ironično u isti mah, ali se, pored svih književnih veza između Foknera i Markesa, može napraviti razlika u pristupu takvim elementima, jer premda obojica kroz svoju fikciju najviše govore o univerzalnim ljudskim tragedijama, oni to čine na donekle različit način. Markes se, naime, na izvestan način odvaja od 
foknerovske tragičnosti koristeći se elementima fantastičnog, čudesnog i ironičnog (2009: 139) i na taj način mnogo je bliži postmodernom pristupu istoriji o kome govori Linda Hačen. Nasuprot Foknerovom izraženom pesimizmu, u svetu koji je stvorio Markes ,strah je ukroćen, a bitke se vode oružjem ironije“ (2009: 139). To, naravno, ne znači da u Markesovom svetu ima manje tragedije nego u Foknerovom, ali su ti elementi kod Markesa prikazani sa nekakvom živošću koja ih, na taj način, ublažava. (2009: 140). S druge strane, ne može se reći ni da kod Foknera nema ironije, ali ona u njegovim delima više naglašava tragičnost, nego što je umanjuje (2009: 139). Na taj način, da se primetiti da je uloga elemenata ironije, mašte i magije kod Markesa višestruka. Pored toga što upotpunjuju sliku stvarnosti, ovi elementi takođe čine da čitalac lakše prihvati neizbežnu tragičnost koja iz takve stvarnosti izvire.

\section{Tragični junaci u večnoj samoći}

Premda počeci oba romana prate analogiju stvaranja sveta i istorije iznova, te potrebu glavnih junaka da prošlost ostave za sobom, njihove sudbine govore u prilog činjenici da je prošlost, kao što je Fokner uvek isticao, neodvojivi deo svakog pojedinca, te da je svaki pokušaj da se od nje pobegne uzaludan. Tomasa Satpena i Hosea Arkadija Buendiju na početku prati ista nevinost, gotovo blaženo neznanje sa kojim pokušavaju da se odvoje od svog starog života. Obojica se nadaju da će zaboraviti prošlost i iznova započeti istoriju, jer su ubeđeni da se, u svetu bez prošlosti, budućnost može prilagoditi njihovom modelu (Zamora, 2006: 194). Međutim, kako obe porodice prati teret incesta, a sa njim i građanski rat, eksploatacija zemlje od strane uzurpatora, porodične tragedije i usamljenost (Zamora, 2006: 194), vrlo brzo postaje jasno da se bolna prošlost ne može tek tako odbaciti, te da je njihov kraj određen već od samog početka. Prati ih, dakle, ista tragična greška koja će se sa osnivača prenositi na njihove potomke i koja će predstavljati tačku u kojoj se spajaju njihova prošlost i njihova budućnost - blistavi početak i apokaliptični kraj.

Foknerov Tomas Satpen predstavljen je, prema rečima kritičara Klinta Bruksa (Cleanth Brooks), kao herojska i tragična figura čija se bezazlenost može uporediti sa Edipovom, a hrabrost sa Magbetovom, dok se prema uticaju koji ima na tuđe sudbine može uporediti sa Konradovim Kercom (2003: 30). Njegovi napori usmereni su na pokušaj da iznova 
stvori sistem koji ga je ponizio, ali tako da sada on bude na vrhu (Parrish, 58-59). Oni nisu, u svojoj srži, motivisani zlim namerama, ali pokreću lavinu događaja koji će odrediti životni tok svih onih koji su povezani sa njim. Satpen na taj način predstavlja primer „bezazlenosti modernog čoveka" - njegovo napuštanje prve žene i sina nije prouzrokovano mržnjom, jer on nikoga ne mrzi, kao što nikoga ni ne voli, samo ima želju da sve u potpunosti podredi svom „dizajnu“ (Brooks, 2003: 21-22). S druge strane, Hose Arkadio Buendija podstaknut je, na sličan način, željom da pobegne od Prudensija Agilara, koga je ubio u borbi petlova. Međutim, njegova potraga za novim svetom proističe i iz njegovog avanturističkog duha, a ogroman poriv za istraživanjem i otkrivanjem raznozaznih pronalazaka jedan je od faktora koji će ga odvesti u ludilo, a potom i u smrt.

Kraj obojice glavnih junaka, kako će se ispostaviti, neraskidivo je povezan sa onim što su pokušali da ostave iza sebe, te je, u oba slučaja, obojen ironijom. U sedmom poglavlju romana Avesalome, Avesalome!, Fokner na maestralan način spaja Satpenov početak, kada je, nakon što mu je jedan rob zabranio da koristi glavni ulaz kako bi ušao u kuću njegovog vlasnika, zaključio da kako bi se „borio protiv njih, mora imati ono što oni imaju“ (Fokner, 1978: 243-244), njegovo napuštanje prve žene i sina koji se nisu uklapali u model koji je zamislio i trenutak kada biva ubijen zbog istog greha zbog kog je i pobegao. Nakon što unuka njegovog sluge, Voša Džonsa, ostaje trudna sa njim, on je odbacuje i ponižava rečima: „Pa, Mili; velika je šteta što nisi i ti kobila. Tada bih ti mogao dati pristojnu pregradu u štali“ (Fokner, 1978: 285). Na taj način, Satpen još jednom pokušava da ostavi za sobom one koji se ne uklapaju u njegov „dizajn“, ali ovoga puta ne zbog crnačke krvi, već zbog činjenice da Mili Džons nije rodila sina, već kćerku. Sada, međutim, ne uspeva da pobegne, jer Voš Džons, gotovo u stanju delirijuma zbog poniženja koje su doživeli on i njegova porodica, ubija i njega i svoju unuku Mili i njenu tek rođenu kćerku. Smrt Markesovog junaka Hosea Arkadija Buendije na sličan način je povezana sa njegovom davnom prošlosću. Međutim, gorka ironija sa kojom se završava život glavnog junaka Foknerovog romana u romanu Sto godina samoće poprima sasvim drugačiji ton, jer je vešto ukombinovana sa elementima fantastike i apsurda. Nakon epidemije nesanice i brojnih neuspeha koje je Hose Arkadio imao sa svojim pronalascima, pojavljuje se njegov davni neprijatelj Prudensio Agilar koji je, kako je u Markesovom magijskom realizmu sve moguće, u smrti ostario: 
Bez Ursulinog nadzora i nege, dozvolio je da ga mašta odvede u stanje večitog delirijuma iz koga se više nikad neće povratiti. Provodio je noći vrteći se po sobi, razmišljajući glasno, tražeći način da se volovska kola, ralo i sve što je u upotrebi pokreće na principu klatna. Toliko ga je umorila groznica nesanice da jedne zore nije mogao prepoznati starca sede glave i nesigurnih pokreta, koji je ušao u njegovu spavaću sobu. Bio je to Prudensio Agilar. Kad ga je na kraju prepoznao, preneražen da i mrtvaci stare, Hose Arkadio Buendija osetio se potresen nostalgijom. ,Prudensio, uzviknuo je - kako si dospeo tako daleko!“ (Markes, 1976: 85)

Na taj način, Prudensio Agilar nije predstavljen kao zli duh prošlosti koji opseda svog ubicu,već gotovo kao prijatelj koji će Hoseu Arkadiju Buendiji, pored Ursule, biti jedino društvo kada ga ukućani vežu za drvo kestena, gde će provesti poslednje godine života. Međutim, nakon što počne da razgovara sa njim, Hose Arkadio počinje da gubi vezu sa ovozemaljskim konceptima, te pod utiskom da je svakog dana ponedeljak zaključuje da se „mašina vremena pokvarila“ (Markes, 1976: 87). Zarobljen u vremenu, on biva obuzet neobjašnjivim besom i tako počinje da ruši sve po kući, te ga zato vezuju za kesten, što čini njegov kraj gotovo tragikomičnim. Pod tim kestenom, u stanju potpunog zaborava u kome više ne ume da govori sopstvenim jezikom, već progovara na latinskom, Hose Arkadio Buendija pred sam kraj vraća se u prošlost za koju nije ni znao da postoji, u stanje „potpune nevinosti“ (Wood, 1990: 28-29), one bezazlenosti sa kojom je i Satpen započeo i završio sa svojim poduhvatima. U tom stanju jedino društvo će mu praviti upravo Prudensio Agilar, koji će „duboko uronjen u smrt, gotovo već pretvoren u prah“ dolaziti da sa njim razgovara o petlovima (Markes, 1976: 150). Dakle, već se na primeru smrti ovih junaka vidi snažna veza između Foknera i Markesa kada je u pitanju povezivanje vremenskih linija koje naglašava neodvojivost sadašnjosti od prošlosti, ali i razlika u prikazu njihovog tragičnog kraja, koji kod Markesa, zahvaljujući elementima magijskog realizma, poprima sasvim drugačiji ton. Pored toga, iako je lik Hosea Arkadija Buendije obeležen tragičnom greškom koja će ga pratiti sve do smrti, njegove postupke ne odlikuje ona nemilosrdnost i svirepost zbog koje strada Tomas Satpen.

Teret prošlosti, nakon Tomasa Satpena i Hosea Arkadija Buendije, nastaviće da prati i sve ostale Foknerove i Markesove junake, zato što se 
nalazi u samom srcu kako američkog Juga, tako i čitave Latinske Amerike. Kao što se neprekidnim ponavljanjem imena u romanu Sto godina samoće naglašava činjenica da pojedinac ne može pobeći od istorije svojih predaka, tako i kod Foknera deca Tomasa Satpena, svako na svoj način, reflektuju njegove osobine. Ovo, paradoksalno, posebno važi za Satpenovog odbačenog sina, Čarlsa Bona, koji je poput njegove „slike u ogledalu“, jer takođe očekuje dete sa ženom koja ima „osminu crnačke krvi“", i spreman je da ih se odrekne (Brooks, 2003: 24). Henri i Džudit Satpen takođe u pojedinim osobinama predstavljaju odraz svog oca - Henri je nasledio očev strah od miscegenacije i spremnost da uradi sve kako bi to sprečio, a Džudit njegovu snagu i stoicizam. Međutim, ono što ove likove odvaja od Tomasa Satpen jeste njhova ljudskost, sposobnost da vole i pate (2003: 27). Henrija Satpena muči „tragična dilema“ jer on ubijajući Čarlsa Bona ubija onog koga zapravo voli (2003: 26) i u tome $\mathrm{i}$ jeste tragedija njegovog lika, u toj unutrašnjoj borbi. Da je predstavljen kao ciničan, sebičan lik, njegovu sudbinu ne bismo shvatali kao tragičnu (2003: 44). Kako gospodin Kompson prepričava Kventinu, Henri je zbog Čarlsa Bona podneo mnoge žrtve:

Jer Henri je voleo Bona. Odrekao se krvnog prava nasleđa i materijalne bezbednosti zbog njega, zbog ovog čoveka koji je u najmanju ruku bio bigamist iz namere ako ne i preispoljna hulja, i na čijem će mrtvom telu četiri godine docnije Džudita naći fotografiju druge žene i deteta. (Fokner 1978: 110)

Pored toga, Henri je takođe jedan od likova čija je sudbina određena davnom prošlošću i koji ne uspeva da izađe iz tog zatvorenog kruga. Zbog očevog greha, kako takođe govori gospodin Kompson, Henri je od početka „osuđen“, jer mu je „sudbina odredila da bude ubica“" (Fokner, 1978: 111). Džudit je, s druge strane, mnogo snažnija od Henrija i pokazuje izuzetnu ljudskost i plemenitost kada, nakon što njen brat Henri ubije Čarlsa Bona na dan njihovog venčanja, učinivši je ,udovicom koja još ne beše postala nevesta“" (Fokner, 1978: 45), dovodi k sebi Čarlsovog nezakonitog sina i brine se o njemu sve dok zajedno ne umru od žute groznice.

Poput Džudit, mnoge ženske likove u romanu Sto godina samoće karakteriše izuzetna snaga i sposobnost obnavljanja, a to posebno važi za Ursulu koja mnogo puta podiže porodicu iz pepela. Ovu snažnu Markeso- 
vu junakinju krase tolika upornost i tvrdoglavost, da čak i kada oslepi od starosti, ne dozvoljava da bilo ko sazna za to:

Snaga njenog nepobedivog srca usmeravala ju je u tmini. Oni koji su primetili njeno teturanje i saplitanje, sa arhanđelskom rukom uvek uzdignutom u visini glave, mogli su pomisliti da joj je teško i sopstveno telo, ali ipak nisu verovali da je slepa. (Markes, 1976:344)

Ursuline osobine, uz pomoć elemenata magijskog realizma, Markes takođe dovodi do granica apsurda, navodeći da je ona, kada je poslednji put brojala, imala između sto petnaest i sto dvadeset i dve godine, kao i da sama može znati da će umreti onda kad u Makondu prestanu kiše. Pored toga, najveća ironija ogleda se u samom Ursulinom kraju, kada se ona počinje sve više i više da se smanjuje, te na kraju postaje poput lutke sa kojom se igraju njeni čukunuci. Smanjivši se na veličinu fetusa, Ursula je „ličila na tek rođenu staricu“ (Markes, 1976: 352), što s jedne strane simbolizuje njenu dotad neprekidnu sposobnost ponovnog rađanja, a s druge, paradoksalno, naznačava njen kraj.

Tragični ton romana Avesalome, Avesalome! i Sto godina samoće pojačavaju i ratovi koji ostavljaju neizbrisiv trag na svest junaka. Nakon što započne Američki građanski rat, gospodin Koldfild, otac Roze Koldfild i Satpenove supruge Elen, krije se na tavanu, gde u jednom trenutku prestaje da jede i tako umire od gladi u potpunoj samoći. Slično se dešava i kod Markesa, samo što je u njegovom romanu tragedija ponovo sakrivena ispod površine apsurda. Nakon trideset i dva rata između liberala i konzervativaca, u kojima je učestvovao pukovnik Aurelijano Buendija, više se ne zna za koju stranu i zbog čega on ratuje. Apsurdnost postupaka pukovnika Aurelijana dodatno je naglašena činjenicom da se on, posle svih tih ratova, zatvara u sobu kako bi pravio zlatne ribice, koje potom prodaje za zlatnike, pa njih ponovo topi kako bi pravio ribice. Ovakve opsesivne navike Markesovih junaka svojim komičnim prizvukom naglašavaju uzaludnost njihovih postupaka, ali su u isto vreme njihovo jedino oružje protiv potpune usamljenosti na koju su svi osuđeni, jer je njihova jedina izvesnost, kao i kod Foknerovih junaka, večita samoća. U samoći će umreti Satpenova supruga Elen Koldfild koja u jednom trenutku postaje „nevidljiva“, tako što se ,povlači u zamračenu sobu koju neće napustiti do svoje smrti dve 
godine kasnije“ (Fokner, 1978: 101). U samoći će umreti i Markesova Rebeka, groteskna junakinja koje se naprasno pojavljuje u porodici Buendija i čije je poreklo nepoznato, ali koja u jednoj kesi nosi kosti svojih roditelja i mahnito jede zemlju. Nakon što, iz nepoznatog razloga, ubija svog muža, Rebeka će ostati sasvim sama u kući i niko više neće čuti za nju sve do njene smrti. Slična sudbina zadesiće Foknerovu junakinju Rozu Koldfild i Markesovu Amarantu koje žive životom Penelope, te sate provode u pletenju i odbijaju svakog ko pokuša da im se približi. Dok Roza Koldfild vreme provodi u pripremanju haljine za Džuditino venčanje koje se na kraju neće ni dogoditi, Amaranta odugovlači sa pletenjem haljine u kojoj će je sahraniti, jer zna, kao i Ursula, da će umreti tačno nakon što je završi. Amarantina razmišljanja pred smrt u velikoj meri sažimaju suštinske ideje romana Sto godina samoće, jer tek tada, dok razmišlja o proscu koga je odbila i Rebeki koju je uvek posmatra kao neprijatelja, shvata da ljudsku tragediju može pojmiti samo ukoliko nauči da razume samoću:

Pokušavajući da što je moguće više odugovlači, Amaranta je poručila laneni konac i sama tkala platno. Kako se približavao neizbežni kraj, shvatila je da bi joj samo neko čudo omogućilo da produži posao i posle Rebekine smrti, ali sama koncentracija pružila joj je mir toliko potreban da prihvati ideju o obmani. Bilo je to kad je shvatila beskonačni krug zlatnih ribica pukovnika Aurelijana Buendije. Svet se suzio na površinu njene kože, i unutrašnjost je ostala spasena svake gorčine. Zabolelo ju je što nije došla do otkrića mnogo godina ranije, kad je još bilo moguće da oplemeni uspomene i sagradi nove svet u novoj svetlosti, i da se bez potresanja seti mirisa lavande Pjetra Krespija u predvečerje, i da spase Rebeku iz njene teške bede, ne iz mržnje ni iz ljubavi, nego zbog neograničenog shvatanja samoće. (Markes, 1976: 289)

Glavne spone između američkog Juga i Latinske Amerike jesu, dakle, teret prošlosti i samoća kao sudbina svih Foknerovih i Markesovih likova i najveća tragedija ljudskog roda. Kada je u pitanju teret prošlosti, kraj i jednog i drugog romana prikazuje da je on toliko jak da ga snažno osećaju i Kventin Kompson, koji se u dvadesetoj godini oseća kao da je „stariji od mnogih ljudi koji su pomrli“ (Fokner, 1978: 363) i pretposlednji potomak porodice Buendija, Aurelijano Babilonija, koji je „svestan svoje 
nemoći da mu duša izdrži mučnu težinu tolike prošlosti“ (Markes, 1976: 424). To je ono što Foknerov Šriv, kao neko ko ne potiče sa Juga, nikada neće biti u stanju da razume - taj „osećaj prisustva prošlosti“", težine istorije koja je prepuna poraza i krivice (Brooks, 2003: 36), i koju može da razume samo neko ko je i sam deo te istorije. Kada je u pitanju prikaz ličnih tragedija likova i njihove samoće, može se zaključiti da se Foknerov i Markesov pristup u tom pogledu donekle razlikuju. Dok kod Foknera pronalazimo čistu tragediju koja je tek u manjoj meri obojena gorkom ironijom, kod Markesa se na površini uvek nalazi sloj ironije, fantastike i apsurda $i$ tek se prodiranjem ispod tih elemenata dolazi do istinske tragedije i najdublje samoće.

\section{Zaključak}

Analiza ova dva romana pokazuje da nesreće Joknapatofe i Makonda počivaju na zajedničkom osećaju tereta istorije, kao i na sveopštoj otuđenosti koja prati sve potomke porodica Satpen i Buendija. Sažimajući u svojim narativima sve vremenske linije, Gabrijel Garsija Markes uspeva da postigne ono ka čemu je težio i Fokner - da u jednoj rečenici obuhvati i prošlost i sadašnjost i budućnost, te da ljudsku sudbinu prikaže kao tačku u kojoj se ova tri koncepta neprestano prožimaju. Takođe, kao i Fokner, Markes tragedije svoje rodne Kolumbije uspeva da pretoči u univerzalno iskustvo, što značaj Makonda čini mnogo većim od samog predstavljanja kolumbijske realnosti. Međutim, surovi svet iz kog crpi inspiraciju za svoje romane Markes fikcionalizuje tako da se slike istinske tragedije mogu primiti sa nekakvom lakoćom, koju ne možemo pronaći kod Foknera. Međutim, to ne čudi, jer sam Markes ističe da je „kraj čoveka“, ta „kolosalna katastrofa" koju je Fokner odbijao da prihvati primajući Nobelovu nagradu za književnost trideset i dve godine pre njega, sada konačno postala „samo jedna od naučnih mogućnosti““ (1987: 211). U takvom svetu, koji više ne nudi čak ni obrise bilo kakve nade u bolje sutra, kao jedino oružje kojim će se boriti protiv toga piscu ostaje samo ironija. 


\section{LITERATURA}

Aiken, C. (1979). Faulkner's Yoknapatawpha County: A Place in the American South. Geographical Review, 3, 331-348.

Brooks, C. (2003). History and the Sense of Tragic. In Fred Hobson (ed), William Faulkner's Absalom, Absalom: A Casebook (pp. 17-46). New York: Oxford University Press.

Delay, F. and J. de Labriolle. (2009). Is García Márquez a Colombian Faulkner?. In Harold Bloom (ed), Bloom's Modern Critical Interpretations: One Hundred Years of Solitude (pp. 25-38). New York: Infobase Publishing.

Delgado, E. (1997). Macondo in Yoknapatawpha: The Exquisite Privilege of Reading William Faulkner's Novels. ANQ: A Quarterly Journal of Short Articles, Notes and Reviews, 2, 33-35.

Eko, U. (2004). Postile uz Ime ruže. U Ime ruže (str. 451- 476). Prev. Milana Piletić. Beograd: Novosti.

Fokner, V. (1978). Avesalome, Avesalome!. Prev. Ljubica Bauer Protić. Beograd: Slovo ljubve.

Hamblin, R. and C. Peek. (1999). A William Faulkner Encyclopedia. London: Greenwood Press.

Hobson, F. (2003). Introduction. In Fred Hobson (ed), William Faulkner's Absalom, Absalom!: A Casebook (pp 3-15). New York: Oxford University Press.

Hutcheon, L. (1988). A Peotics of Postmodernism: History, Theory, Fiction. New York and London: Routledge.

Llosa, M.V. (1997). William Faulkner: The Sanctuary of Evil. In John King (ed. and trans.), Making Waves: Essays (pp. 153-158). New York: Farrar, Straus And Giroux.

Markes, G.G. (1976). Sto godina samoće. Prev. Jasna Mimica-Popović. Beograd: Beogradski izdavačko-grafički zavod.

Márquez, A. (1992). Faulkner's Presence in Latin American Literature. REDEN: revista española de estudios norteamericanos, 5, 11-25.

Márquez, G.G. (1987). The Solitude of Latin America: Nobel Address 1982. In Bernard McGuirk and Richard Cardwell (ed), Gabriel García Márquez: New Readings (pp. 207-211). Cambridge: Cambridge University Press.

McHale, B. (1987). Postmodernist Fiction. London and New York: Routledge.

Meyers, K. (1986). The Coded Beginning: Meaning in the First Sentence of Cien años de soledad, Confluencia, 1, 33-38.

Parrish, T. (2008). From the Civil War to the Apocalypse: Postmodern History and American Fiction. Amherst: University of Massachusetts Press. 
Wood, M. (1990). Gabriel Garcia Márquez: One Hundred Years of Solitude (Landmarks of World Literature). Cambridge: Cambridge University Press.

Zamora, L.P. (2006). Apocalypse and Human Time in the Fiction of Gabriel García Márquez." In Harold Bloom (ed), Bloom’s Modern Critical Views (pp. 183-216). New York: Chelsea House Publishers.

Milica S. Stanković

$$
\begin{gathered}
\text { HISTORY, TRAGEDY AND IRONY IN WILLIAM FAULKNER'S } \\
\text { ABSALOM, ABSALOM! AND GABRIEL GARCÍA MÁRQUEZ'S } \\
\text { ONE HUNDRED YEARS OF SOLITUDE }
\end{gathered}
$$

\begin{abstract}
Summary
This paper provides a comparative analysis of William Faulkner's novel Absalom, Absalom! and Gabriel García Márquez’s One Hundred Years of Solitude, paying special attention to their depiction of the past and the elements of tragedy. Starting from Faulkner's impact on Latin American literature of the second half of the $20^{\text {th }}$ century known as "the Boom", to the concepts of Yoknapatawpha and Macondo and the postmodernist approach to history, the paper strives to provide an insight into the strong connection between Faulkner's and Márquez's portrayal of their characters' tragic past, which is inseparable from their present and which will accompany them until the apocalyptic ending of both novels. Furthermore, particular attention is devoted to the elements of irony, which are crucial for any attempt of revisiting history. Since they are much more dominant in Márquez's narrative, they also represent a major difference between his and Faulkner's approach to the sense of tragedy.
\end{abstract}

Key words: Faulkner, Márquez, history, historiographic metafiction, tragedy, irony 